\title{
PATRIARCHY AND JUSTICE FOR WOMEN IN AFRICA - RUTH, TAMAR
}

Dirk Büchner

University of Durban-Westville

\section{Abstract}

The story of Tamar and Judah in Gen 38 is a well-told drama that is a rich source of ancient near-eastern cultural practices. Many related ideas are found in the story of Naomi, Ruth and Boaz as told in the book of Ruth. These two stories are subversive of the Bible's patriarchal system as it defines the social position of widows without children. The status of widows is highlighted as a status defined for them by their culture, and which may be challenged. The result of the widows' subversive behaviour is, of course, offspring. Moreover, these male (!) children find themselves in the ancestral list of David and eventually of Jesus in Matthew 1. Notable too is that Matthew mentions both Ruth and Tamar by name on a list normally reserved for males, so their subversion has a long-term effect. Much of the cultural material in the two Bible stories are very similar to traditional African culture and the status of women in these cultures. This makes the stories an excellent teaching resource in an African context. In this article I will summarise the response I have had from male and female African students who have interacted with these stories. Initially, therefore, I will not be giving my own viewpoint, but the views of African readers and writers. From this information I want to make a few comments about where we are as regards patriarchy and feminism. Also I wish to stimulate some discussion about feminism and the Bible within the African context. Some welcome feminism as a liberating perspective, but others perceive it as another ideological notion imposed on African church and culture by non-African interpreters of the Bible.

\section{The biblical customs in Gen $\mathbf{3 8}$ and their African equivalent}

The order in which they appear in the story, are as follows:

\begin{tabular}{|c|c|}
\hline $\begin{array}{l}\text { ANCIENT NEAR EASTERN } \\
\text { CUSTOM }\end{array}$ & AFRICAN PARALLELS \\
\hline $\begin{array}{l}\text { 1. Hirah is Judah's friend who } \\
\text { negotiates with the bride's family about } \\
\text { the conditions of marriage. Henceforth } \\
\text { he remains a life-long friend and } \\
\text { confidant. }\end{array}$ & $\begin{array}{l}\text { In some African communities, negotiations are } \\
\text { done by means of an intermediary. Also, } \\
\text { husbands have an intimate friend who may have } \\
\text { sexual relations with his wife when he is away } \\
\text { (Beya 1992:158). }\end{array}$ \\
\hline $\begin{array}{l}\text { 2. The father of the clan is responsible } \\
\text { for the family's well-being. This } \\
\text { includes choosing wives for his sons. }\end{array}$ & $\begin{array}{l}\text { This is a widespread practice in Africa, although } \\
\text { it is usually done with the consent of the children } \\
\text { themselves. Parents participate in marriage } \\
\text { arrangements to ensure the continuation of family } \\
\text { lines (Mbiti, 1974:135-6, Paris, 1995:82ff.). }\end{array}$ \\
\hline $\begin{array}{l}\text { 3. Because of the vague idea of afterlife } \\
\text { in the Old Testament, a person's }\end{array}$ & $\begin{array}{l}\text { Preserving the name of the deceased is very } \\
\text { important in Africa. The Zulu custom of }\end{array}$ \\
\hline
\end{tabular}


immortality consisted in his having children (Sienstra, 1993:78). In order to prevent the deceased husband's name from being forgotten, childless widows may be married to another male from the same family who will generate offspring.

4. Allied to this is the principle that land and property must be kept inside the family's protection and may not be sold outside the family. ukungena is similar to the levirate of biblical times. Also in Africa one find the custom of ghost marriages where a close relative is chosen to act as genitor. The family take care of the girl and the children born to her assume the dead man's name (Bahemuka 1992:122).

The extended family includes those who have gone before and those who are still to be born. Tribal land is therefore a very important thing and a very sore point in our history.
5. The firstborn's inheritance is a source of envy to the other brothers. Generally the firstborn son inherits double the other children's share. This is the reason for Onan's unwillingness to generate offspring for his dead brother.

6. The prevention of offspring for whatever reason is viewed as detrimental to the family at large and is taboo.

7. Wrongdoing in this area may result in premature death, euphemistically described as 'God killed him'. Alternatively, premature death may be explained as divine retribution upon a misdeed in the community.

7. A woman sexually wronged is unable to turn to the community for redress, because it is shameful to her, but not to the community leaders.

8. A widow is at the mercy of her fatherin-law, the patriarch of the family.

9. Childless widows are abject and have no property rights.

10. A twice-widowed childless woman is viewed as a threat to the survival of the clan and sent home to her father's house. This is the worst position of shame for a woman.
'A childless marriage constitutes a major moral and spiritual problem for all concerned' (Paris, 1995:79) In many cases marriage is not considered consummated until pregnancy occurs (Paris, 1995:112).

To die young and childless is disastrous and often denotes punishment for wrongdoing (Paris, 1995:113).

Any girl with a dubious sexual history will find that it marginalises her from her community and this means social invisiblity (Armour 1991:165).

A widow is at the mercy of her in-laws (Oduyoye 1992:16).

This is the case in most traditional African societies (Nwachuku 1992:69). Of the unmarried woman, Beya (1992:163) says: 'Their unmarried state of life wins them no respect from others'.

Girls who for one reason or another do not fulfill requirements for marriage are ostracised (Beya 1992:156). In African tradition this assumes the return of the bride-price. African men will immediately make the association: being sent 


\begin{tabular}{|c|c|}
\hline & $\begin{array}{l}\text { home to parents is the punishment for adultery } \\
\text { (Beya 1992:160) }\end{array}$ \\
\hline $\begin{array}{l}\text { 11. A bereaved husband must fulfill a } \\
\text { required time of mourning, after which } \\
\text { he is free to asociate with- and even } \\
\text { have intercourse with women, which } \\
\text { draws no adverse social comment. }\end{array}$ & $\begin{array}{l}\text { Males are sometimes restricted for one year from } \\
\text { remarrying, but there is no required ritual. There } \\
\text { is great leniency accorded to males (Nwachuku } \\
\text { 1992:63). }\end{array}$ \\
\hline $\begin{array}{l}\text { 12. No father may lawfully marry the } \\
\text { wife of his son. This is regarded as } \\
\text { incest (Lev 18) }\end{array}$ & $\begin{array}{l}\text { In the case where a bride is designated to an } \\
\text { immature son in an arranged marriage, no father } \\
\text { may become genitor to a bride designated to his } \\
\text { son. This is tantamount to incest. (Bahemuka } \\
\text { 1992:122). }\end{array}$ \\
\hline $\begin{array}{l}\text { 13. Clan chiefs carry important markers } \\
\text { of authority. To have possession of } \\
\text { someone's totem or personalised items } \\
\text { means to have power over them. }\end{array}$ & \\
\hline \multicolumn{2}{|l|}{$\begin{array}{l}\text { 14. Goats are marvellous mobile gifts or } \\
\text { objects to use for bartering. }\end{array}$} \\
\hline $\begin{array}{l}\text { 15. Women caught in the act of } \\
\text { intercourse outside of marriage may be } \\
\text { sentenced immediately but similar } \\
\text { behaviour by males created no outcry } \\
\text { among the community. Extra-marital } \\
\text { sex on the part of the woman is adultery, } \\
\text { though on the part of a man it is not } \\
\text { (Sienstra, 1993:84,5). }\end{array}$ & $\begin{array}{l}\text { There are different degrees in punishment of } \\
\text { males and females for suspected infidelity } \\
\text { (Kanyoro 1992:89, Beya 1992:159). }\end{array}$ \\
\hline $\begin{array}{l}\text { 16. Name-giving is often associated } \\
\text { with circumstances at the time of birth } \\
\text { or with the personality of the child. }\end{array}$ & $\begin{array}{l}\text { An event happening at the time of birth is one } \\
\text { aspect of name-giving in Africa (Nasimiyu- } \\
\text { Wasike 1992:50). In Africa, names also depict the } \\
\text { nature of the child's personality and destiny, as } \\
\text { far as the latter may be known (Paris, 1995:103). }\end{array}$ \\
\hline
\end{tabular}

\section{Modern interpretation of the Ruth and Tamar stories}

Modern commentators on the Tamar story, including Nidich (1979), Alter (1981), Myers (1988), Brenner (1994) and Wildavsky (1994) all agree that this is a critique on the cultural oppression of widows' inheritance rights and the levirate. Tamar acts subversively in getting what is hers by law when it is withheld from her by the patriarch of the family. Ruth does the same thing, to a certain extent, by entering the male enclave of the threshingfloor and putting Boaz in an embarassing situation, forcing his hand, as it were, to act in allowing her mother-in-law Naomi to regain ownership of her family plot of land and have male offspring to care for her. Both women do not remain passive in the face of oppressive tribal custom, but use their initiative, place their reputations on the line and get what they want. Crucial is the fact that their success is not dependant upon divine intervention. In both stories patriarchal figures are turned into anti-heroes. Judah's efforts to save his last remaining son through deceiving Tamar in the hope that she would stay at home, is the lowest point in the story and is that action most condemned by the writer: Judah placed the 
survival of his family above the moral law (Wildavsky 1994:43). The change in the prostitute-nomenclature from זונה (common prostitute) to קדשה (religious functionary) is interesting. Hirah is embarassed at having to deliver the goat. He denies the affair and pretends that he is taking the goat to a sacred prostitute for a sacrifice as in Hos 4:14 (Westenholz, 1989:248).

Another aspect of both stories is that they are subversive of primogeniture (Wildavsky 1994:42) and also of the anti-foreigner, purity drive of Ezra's time. Here is a snapcomparison of Ruth and Tamar:

\section{New Testament}

\begin{tabular}{|c|c|}
\hline Tamar (Gen 38) & Ruth \& Naomi \\
\hline $\begin{array}{l}\text { Tamar is a foreigner (Canaanite) denoting } \\
\text { prior marginilisation }\end{array}$ & $\begin{array}{l}\text { Ruth is a foreigner (Moabite) denoting } \\
\text { prior marginilisation }\end{array}$ \\
\hline Childless widow & Ruth \& Naomi are childless widows \\
\hline $\begin{array}{l}\text { Suffers under cultural oppression typical of } \\
\text { women in patriarchal societies: inability to } \\
\text { carry the name of- or inherit a deceased } \\
\text { husband's goods or land without male } \\
\text { offspring from the family }\end{array}$ & The same \\
\hline $\begin{array}{l}\text { Additional position of shame, unable to seek } \\
\text { public redress for sexual wrong, and also } \\
\text { tricked by father-in law in the name of the } \\
\text { survival of his family. }\end{array}$ & \\
\hline $\begin{array}{l}\text { No begging God for help in position of } \\
\text { weakness, but takes own initiative }\end{array}$ & $\begin{array}{l}\text { Naomi makes clever plans to place Ruth in } \\
\text { the right place at the right time }\end{array}$ \\
\hline $\begin{array}{l}\text { Undergoes role-change from widow to } \\
\text { seducer of Judah. This happens at festival- } \\
\text { time of shearing the sheep }\end{array}$ & $\begin{array}{l}\text { Undergoes role-change from homeless } \\
\text { wanderer to seducer of Boaz. This happens } \\
\text { after festivities at harvest-time }\end{array}$ \\
\hline $\begin{array}{l}\text { Judah generates offspring for Tamar's dead } \\
\text { husband, Er, whose name is not to be } \\
\text { forgotten }\end{array}$ & $\begin{array}{l}\text { Boaz raises offspring for Mahlon, whose } \\
\text { name is not to be forgotten }\end{array}$ \\
\hline $\begin{array}{l}\text { Judah was embarassed by Tamar, who had } \\
\text { him in her power by keeping his personal } \\
\text { effects. }\end{array}$ & $\begin{array}{l}\text { Boaz is embarassed to find a woman lying } \\
\text { at his feet, because somehow she had him } \\
\text { in her power. }\end{array}$ \\
\hline $\begin{array}{l}\text { Tamar is publicly accused, but then publicly } \\
\text { honoured: 'she is more in the right than I' is } \\
\text { Judah's confession. }\end{array}$ & $\begin{array}{l}\text { Ruth is given a public blessing in the town } \\
\text { gates, and compared to Tamar, Rachel and } \\
\text { Leah }\end{array}$ \\
\hline $\begin{array}{l}\text { Tamar and her offspring are mentioned in } \\
\text { David's list of ancestors }\end{array}$ & Ruth's son is David's grandfather \\
\hline $\begin{array}{l}\text { Tamar's sexual act is viewed as morally } \\
\text { good because it enhanced the community }\end{array}$ & $\begin{array}{l}\text { Ruth's actions with Boaz are described as } \\
\text { kindness rather than seductive behaviour }\end{array}$ \\
\hline $\begin{array}{l}\text { The one who refuses his duty is killed by } \\
\text { God before he could be taken to the town } \\
\text { elders for the sandal custom (Dt 25) }\end{array}$ & $\begin{array}{l}\text { The one who surrenders his duty as close } \\
\text { relative is not viewed in a bad light, but } \\
\text { takes off his sandal as a testimony that he } \\
\text { gave the right to Boaz }\end{array}$ \\
\hline
\end{tabular}




\section{Erpretation of the stories by African readers}

The message for the most ordinary woman-reader in the African context is immediate: the patriarchs are made to look fools for their behaviour towards women. Therefore, the message for marginalised women is: if your culture is oppressing you and withholding your rights, don't blindly accept it; do something! You are likely to succeed!

The male reader has a different perspective. Tamar is a childless widow, but is given privileged status under the custom of ukungena and the right to have children. When she is sent back to her father's house, she must remain there until told what to do. This is what any self-respecting woman ought to do. Besides, any woman sent back to her father's house must have done something very shameful. Judah acted correctly in considering his options for saving his remaining son, even if it meant deception. Furthermore, Tamar's disobedience, her acting the prostitute and her seduction of Judah is reprehensible. A woman already tainted by being sent home, now changes roles into a deceiver who brings harm to the man who is the target of her anger. She gets hold of his personal items in order to exert power over him (cf. Thorpe, 1991:46 on role change and evil wrought by women in Zulu culture). No wonder he has to undo this evil by bringing a goat! On being found out, she deserves to be punished for this behaviour.

This shows:

1. African women students are quick to express, be it only under cover of written answers, their discontent with their lot under patriarchy. They are pleased to find in the Bible a critique of patriarchy and a link to their own feelings.

2. There is a reluctance among male students to acknowledge this discontent and to perceive patriarchy as being at all negative.

3. In spite of their protest, I get the impression that African women still do not dare openly challenge male sex roles that cause them physical and mental anguish.

\section{African impressions of patriarchy vs feminism in the literature and open discussion}

African feminist writers give a very negative evaluation of patriarchy. Here and there one finds voices acknowledging the value of patriarchal practices defined for women, but overall, African women are unhappy with the patriarchal system. This is evident also from the abundant literature produced by African women on this topic (cf. Ackermann, et. al. (1991), Sanders, et. al. (1995) and Oduyoye, et.al. (1992). Unfortunately, I have not yet come across any reference to Tamar from an African woman writer.

Male students and church leaders, when asked if patriarchy is oppressive, naturally say: 'not at all'. To the question of whether women will be afforded different status than that defined by patriarchal custom, male students say: 'Never'. 'The women will become spoiled'. Thus, what is to many a healthy contextualising of the Bible, is to others a sellingout of African culture in favour of Western culture (cf. Mpulwana 1991:376). Hence, the Bible is being perceived once again as a tool by which cultural ideas that have been entrenched in the African community for centuries, are being undermined. African theological thought, having just survived the-Bible-and-apartheid are now once again coming under attack to surrender to the-Bible-and-feminism. Govinden (1991:287), Hinga (1992:183) and Jacobsen (1994:148) all caution us on this point, but do not suggest how to bridge the perceptional divide. 


\section{Toward a solution in teaching the bible between patriarchy and feminism in Africa}

The Bible needs to be two things. It needs firstly, to be de-westernised for African students. Modern African students of the Bible need to feel comfortable about owning the Bible as theirs in the post-Apartheid era without compromising their Africanness. Secondly, the Bible needs to be held up as a tool of liberation for today. For women suffering under patriarchy, the Bible can be very liberating, and exegeting stories like those of Ruth and Tamar are excellent examples of how this can be done. For males, the Old Testament is non-Western, and quite African in terms of its concept of time ${ }^{1}$, the importance of remembering of ancestors, immortality by having offspring and the system whereby the family is the greatest good. The Old Testament is liberating in its views on land ownership and criticism of oppressive government structures, to mention just two.

The solution lies in finding a compromise between how one allows the Bible to speak to preservation of a social system that is being threatened by rapid westernisation and at the same time letting the Bible speak to ridding that system of oppressive elements. At the present time it seems that firstly, the divide between traditional patriarchal ways and feminist voices in African society is still far too wide. No African feminist writer I have read satisfactorily answers the question Mandew raises (1991:130): 'If we accept that patriarchy is an unjust system, we have to ask ourselves why it has persisted for so long'(italics mine). Instead of answering the question, he rephrases it as follows, which I think misses the point: 'If Christianity (and the church) preaches justice and the equality of all, how is it that patriarchy, a system which militates against the ideal of justice and the equality of all, has persisted for so long, not only in society, but especially within the Christian community?' His rephrased question already assumes that African patriarchy is and always has been oppressive, and many Africans will disagree immediately. On what basis is it 'accepted' that patriarchy is by nature an unjust system?

Secondly, the problem is that most of the literature on women and the Bible is written by women for women and do not have males participating in active dialogue. This became apparent to me when I attended the session of the group Women in Africa at the AAR in New Orleans in November 1996. Women were speaking for women in the rhetoric of the underdog, of the need to arise, the need to use their initiative, the need to change their attiudes about themselves. But the solution to the oppression did not become apparent. There were no males actively participating in the dialogue. The cumulative impression I get of feminist rhetoric is that it addresses women to do something about their position when it is really the males that have to change their attitude and do something about the women's position. 'How can I arise and walk when our men continue to break my knee-joints?' asks Musopole (1992:204). Unfortunately, she ruins a good article by concluding only with questions rather than suggestions. It seems to me as if the reason for this is that the patriarchal system in Africa is still untouchable. In Ackermann, et.al. (1991) the male contributors write only in support of feminism (and legitimately so), but do not address male-centredness from an intra-African angle. Surely that is a big omission. An African male reader will say that they are writing solely from a western point of view. Students I have quizzed on Martin Mandew (1991:131) quoting Ramodibe (1988:15) in the same collection of essays: 'African tradition and culture present themselves to women as an oppressive system' said: 'that is not true!'

1 In Isaiah 43, for example, the past is expressed by the terms i.e. that which lies before us. The future is that which is behind אחרית. This is exactly the African sense of time. 
A similar reaction will meet Govinden's urge to 'dismantle patriarchy in a deliberate and systematic way' (1991:278). This is a most un-African proposal. We cannot just dismantle African patriarchy, because it is not negative per se. A root of role conflicts is that in traditional societies, religion and culture are inseparable and the ancestor-cult is patriarchal (Nwachuku 1992:55). The latter aspect is a big problem to feminism, for to western writers, patriarchy is an ideology, but in Africa, it is much more. It is a system within the concept of the community's welfare as the highest good, and integral part of the sacramental view of life (cf. Paris, 1995:132). Oduyoye herself has been accused of losing her Africanness (Govinden 1991:278). Is the male perspective that western feminist theology is neocolonialist, intransigence (Mandew 1991:142) or is it something else? Govinden mentions it as the 'spectre of Western feminism' (1991:287), but does not realise that it is to traditional Africans not a spectre but something real. Black males are not involved in the dialogue through literature, because they do not assume that the patriarchal system is what it is, seen from the western feminist viewpoint. Nwachuku's solution to me seems the most plausible: traditionalism needs to condemn dehumanisation without losing what is traditional (1992:72).

\section{Conclusions}

I have tried in this article to point out that

1. Gen 38 and Ruth strike a chord with African women who need to see the Bible as a liberating book. These stories undermine the Bible's own patriarchy. The women gain lasting fame by their subversive actions.

2. This goes against the grain of the traditional African male perspective of propriety for women. But the stories can show males that survival should not be gained through oppression (cf. Wildavsky, 1994:42-3).

3. The task of the biblical scholar in Africa is to gradually make males participate more actively in the dialogue. As cultures change and interact with each other, the question needs to be asked: what does social change mean to traditional Africans? If African males are to be involved in social change, they must be recognised as role-players and not as an antagonists to the process.

In my efforts to contextualise the Bible to African students of Biblical Studies who hold very securely to traditional beliefs, I have tried to push the Old Testament's Africanness. For women, it is a patriarchal book but yet contains some conflicting ideology that undermines that patriarchal aspect. Alternatively, it is a book which by virtue of its cultural make-up appeals to the traditional African rather than to the Westerner. The Israelite experience from beginning to end reads like an African story. Israelite culture never remained static, but underwent changes as the Israelites came into contact with hostile cultures. The Old Testament often asks its readers: 'what is permissible when your culture is threatened with extinction?' (Wildavsky, 1994:42). In the time of Ezra, saving the Jewish culture and religion from extinction meant getting rid of foreign wives. Yet, both Ruth and Tamar are foreign women whose names and the names of their offspring are included on the Messiah's ancestral list. Thus the Old Testament reader sees an internal dialogue in the Bible on the merits and demerits of protecting one's cultural identity at the expense of basic morality. This is where we are now in African Biblical Studies: subjecting the Bible's ideology and our own to a critique in the light of what is best for the community. 


\section{BIBLIOGRAPHY}

Ackermann, D, Draper, J and Mashinini, E 1991. Women hold up half the sky. Women in the Church in Southern Africa. Pietermaritzburg: Cluster Publications.

Alter, R 1981. The Art of Biblical Narrative. London and Sydney: George Allen \& Unwin.

Armour, M 1991. Forbidden Agendas: Feminist Theology and the Politics of Sexuality, in Ackermann, D, Draper, J and Mashinini, E 1991, 161-168.

Bahemuka, JB 1992. Social Changes and Women's Attitudes toward Marriage in East Africa, in Oduyoye, MA and Kanyoro, MRA (eds.) 1992, 119-134.

Beya, BM 1992. Human Sexuality, Marriage and Prostitution, in Oduyoye, MA and Kanyoro, MRA (eds.) 1992, 155-182.

Brenner, A 1994. The Israelite Woman: Social Role and Literary Type in Biblical Narrative. Sheffield: JSOT Press.

Davies, EW 1993. The Inheritance of the First-Born in Israel and the Ancient Near East. JSS 35/3, 175-191.

Draper, JA 1991. Oppressive and Subversive Moral Instruction in the Nwe Testament, in Ackermann, D, Draper, J and Mashinini, E 1991, 37-54.

Edet, RN 1992. Christianity and African Women's Rituals, in Oduyoye, MA and Kanyoro, MRA (eds.) 1992, 25-39.

Govinden, B 1991. No Time for Silence: Women, Church and Liberation in Southern Africa, in Ackermann, D, Draper, J and Mashinini, E 1991, 274-297.

Hinga, TM 1992. Jesus Christ and the Liberation of Women in Africa, in Oduyoye, MA and Kanyoro, MRA (eds.) 1992, 183-194.

Jakobsen, W 1994. Ethics in Feminist Theology in: Villa-Vicencio, C and De Gruchy, JW (eds.) 1994, 148-160.

Kanyoro, MRA 1992. Interpreting Old Testament Polygamy through African Eyes, in Oduyoye, MA and Kanyoro, MRA (eds.) 1992, 87-100.

Mandew, M 1991. The Challenge of Black Feminist Theology in South Africa: a Black Male Perspective, in Ackermann, D, Draper, J and Mashinini, E 1991, 129-144.

Musopole, AN 1992. Sexuality and Religion in a Matriarchal Society, in Oduyoye, MA and Kanyoro, MRA (eds.) 1992, 195-205.

Myers, CM 1988. Discovering Eve: Ancient Israelite Women in Context. Oxford: Oxford University Press.

Nasimiyu-Wasike, A 1992. Christianity and the African Rituals of Birth and Naming, in Oduyoye, MA and Kanyoro, MRA (eds.) 1992, 40-53.

Nidich, S 1979. The Wronged Woman Righted: An Analysis of Gen 38. HTR 72, 143-49.

Nwachuku, DN 1992. The Christian Widow in African Culture, in Oduyoye, MA and Kanyoro, MRA (eds.) 1992, 54-73.

Oduyoye, MA and Kanyoro, MRA (eds.) 1992. The Will to Arise. Women, Tradition and the Church in Africa. New York: Orbis.

Paris, P 1995. A Spirituality of African Peoples. Minneapolis: Fortress.

Sanders, CJ (ed.) 1995. Living the Intersection. Feminism and Afrocentrism in Theology. Minneapolis: Fortress Press.

Van der Toorn, K 1994. From her Cradle to her Grave. Sheffield, JSOT Press. 
Van der Toorn, K 1995. Torn Between Vice and Virtue: Stereotypes of the Widow in Israel and Mesopotamia, in Kloppenborg, R and Hanegraaff, WJ (eds.) Female Stereotypes in Religious Traditions. Leiden: Brill, 1-13.

Villa-Vicencio, C and De Gruchy, JW (eds.) 1994. Doing Ethics in Context: South African Perspectives. Johannesburg: David Philip.

West, GO 1991. Silenced Women Speak: Feminist Biblical Hermeneutics, in Ackermann, D, Draper, J and Mashinini, E 1991, 79-91.

Westenholz, JG 1989. Tamar, Qedesa, Qadistu, and sacred prostitution in Mesopotamia. HTR 82:3, 245-65.

Westermann, C Genesis 1-12. BKAT I. Neukirchen-Vluyn: Neukirchener Verlag.

Wildavsky, A 1994. Survival must not be gained through sin: the moral of the Joseph stories prefigured through Judah and Tamar. JSOT 62, 37-48. 